\title{
English Teacher Identity in the Context of Zoning Policy Implementation
}

\section{Anita Galuh Sri Hapsari1 ${ }^{*}$, Markus Budiraharjo ${ }^{2}$}

1,2 Magister Pendidikan Bahasa Inggris, Universitas Sanata Dharma

\section{A R T I C L E I N F O}

Article history:

Received 15 August 2019

Received in revised Form 29 September 2019

Accepted 18 October 2019

Available online 29

November 2019

Keywords:

English teachers; teacher identity; zoning policy; high-performing school; low-performing school

\begin{abstract}
A B S T R A C T
Teacher identity still remains an important topic to discuss in education because it shows teachers' personal and professional aspects. Teacher identity is not a static circumstance as it changes depending on the contexts. As zoning policy in new student admission in Indonesia remains as educational current issue, this study aims to explore how the zoning policy implementation develops English teacher identity in high and low-performing schools. This study employed qualitative approach as the purpose of this research is not to be generalized; this empirical research is aimed to reveal holistic discussion of particular subjects instead. Twelve English teachers from different public senior high schools in Yogyakarta Province, Indonesia were selected for semi-structured interviews and two of them were invited to have in-depth interviews. The data were coded and analyzed based on the framework of teacher identity construction. The results showed that the contribution of zoning policy implementation in teacher identity development varied. Firstly, zoning policy implementation influences teacher identity regarding their beliefs on students' characteristics in high and low-performing schools. Secondly, teachers' maintenance of their moral purpose as educator was developed through the implementation. Thirdly, class dynamics were triggered by the previous two aspects
\end{abstract}




\section{Introduction}

Teacher identity is not a static entity as it is changing all the time based on the situational contexts, such as a teacher's experiences, practices, activities, and policies. These aspects affect how teachers make meaning of her/himself as a teacher within the social and cultural life (Richardson \& Watt, 2018). Teacher identity is understood to relay to fundamental features of teachers' professional lives regarding their notion of a teacher's role, motivation to teach, choice of methods, willingness to adjustment, and the path of professional learning and growth (Kaplan \& Garner, 2018). Hence, teacher identity refers to "ascribed identity" (Richardson \& Watt, 2018) as a teacher's identity is gained from his/her personal agency, choice, determination and perseverance.

In educational sector, the role of teacher identity is important. A teacher's identity can be shown in his/her storylines of experience and thoughts on the values they follow in his/her teaching (Pennington \& Richards, 2016). A teacher's personal characteristics potentially affect his/her teaching in class. Teacher identity, moreover, plays an important role in emerging effective teachers and teaching quality (Hong, Francis, \& Schutz, 2018). Therefore, teacher identity has a close association to the class dynamics and quality of effective and meaningful teaching. Further, it impacts on the students' learning process and attainment.

Teacher identity is affected by macro and micro levels. A macro level refers to the educational policy made by the government in the country. This level of influence is wider than in the scope of school context. Meanwhile, a micro level of influence happens at the school context which includes relation between teachers-students, teachers-colleagues, teachers- school authority, and teacher- students' parents (Hong et al., 2018). Furthermore, the development of teacher identity begins from oneself and is followed by the state of affairs and the environment (Viskovic \& Robson, 2001).

Considering the essence of teacher identity in educational context, it is needed to explore teacher identity development in particular current context. This current research aims to investigate English how teachers' identity is shaped within the context of zoning policy implementation in new student admission in public senior high schools in Yogyakarta Province, Indonesia. It is needed to find out how zoning policy which becomes current debating issue in Indonesian educational setting gives influences to teacher identity development. Furthermore, the study on teacher identity within the context of the Indonesian government's new policy in the student enrollment is still underdeveloped. This study will give contribution to the literature on teacher identity, particularly related to macro and micro levels in Indonesia. Hence, future researchers can make use of this research results to conduct further research on teacher professional identity development. To understand the background of this study, the researchers review the zoning policy in Indonesia in the recent years.

It has been years that senior high schools in Indonesia, particularly in Yogyakarta Province, were labeled by society as favorite and non-favorite schools regarding the quality (Amirin, Wijayanti, \& Safruddin, 2016). Favorite schools refer to the schools which become the first choice for junior high students with high academic attainment to continue their study in the next level. These schools are usually located in the city or district center. Non-favorite schools refer to schools which become the second or third choice due to low academic attainment. These schools are usually located outside the city or district center. In this research, favorite schools are seen as high-performing schools while non-favorite schools are seen as low-performing schools. Both of the schools are public schools.

In order to erase the labeling and to give students equal opportunities to attend public schools, zoning policy in new student enrollment has been implemented in these past two years in Indonesian public schools. The policy is expected to conduct the admission process fairly in which all students living in the set radius from the schools have the same opportunity to pursue their education in the nearby schools (Ali, Bakar, Supriyati, \& Hanafi, 2019). The Ministry of Education and Culture states that one of the purposes to implement zoning policy in the student admission is to make equal distribution of students to pursue their study in public schools (Hoerudin, 2019). Perdana (2019) showed the successful implementation of this policy in Sulawesi Tengah Province. On the one hand, students attended closer schools. On the other hand, the dichotomy of favorite and non-favorite schools has significantly reduced.

Yet, obstacles of the implementation of this policy still emerged as stated by several parties, such as stakeholders and society (Adiputra, Karsidi, \& Haryono, 2019; Bintoro, 2018). The preliminary interviews conducted for this study also revealed that teachers felt the changes of students' characteristics and class dynamics after the implementation of zoning policy in these recent years. The preliminary interviews indicated the changes of teacher's belief have triggered teacher identity change after the zoning policy implementation. 


\section{Statement of the Problem}

To conduct this study, one research question is formulated; that is "what identity do English teachers demonstrate upon the implementation of zoning policy in high and low performing schools in Yogyakarta?"

Objective of the Study

Based on the background and problem formulation, this study aims to dig out how the new policy implementation affects teacher identity in low and high-performing public schools in Yogyakarta province.

\section{Methods}

To investigate the English teacher identity construction in the context of zoning policy implementation, this research employed basic qualitative study proposed by Ary, Jacobs, \& Sorensen (2010). The study took places in twelve public senior high schools in Yogyakarta Province. The twelve schools were chosen with purposive sampling based on the district geography locations, namely Sleman, Bantul and the city of Yogyakarta. The first sampling criterion was based on the demographic conditions of the students in the three districts in which the high-performing students tended to pursue their secondary education in high-performing schools in the city of Yogyakarta. With zoning policy implementation of new student admission, students whose addresses were in Sleman and Bantul districts encountered a huge hurdle to get enrolled in schools in Yogyakarta city.

The second sampling criterion was the school ranks depending on the national examination average scores gained by the new students in the admission selection. The researchers chose two highperforming and two low-performing schools in each of the district. Hence, four schools in each district were involved in this study.

The researchers spent three months to collect the data. Before starting the research, the researchers obtained permission letter from the Department of Education and Culture of Yogyakarta Province. Then, the researchers met the school administrators to explain the inquiry and to invite them to take a part in this research. When the school agreed to voluntarily join the research, consent forms were given and signed by the school principals. Interview schedule was then arranged by the schools on behalf of the English teachers handling class 10. Figure 1 summarized the steps taken for this research.

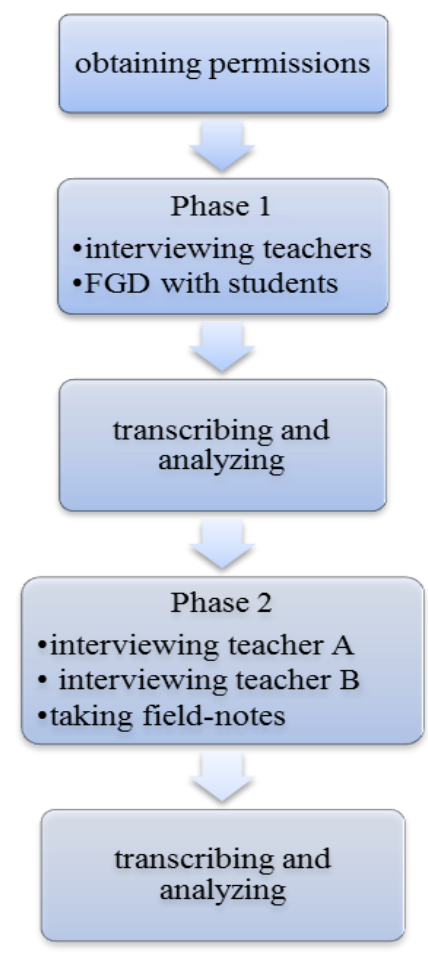

Figure 1. Research Procedure 
There were two phases of data collection technique. First, semi-structured interviews with twelve English teachers in the twelve schools were conducted. The audio-recorded interviews lasted for 25-35 minutes for each teacher. The interview data were transcribed and given initial labels, such as students' characteristics in English classes, challenges faced by the teachers in teaching English, teachers' perception on zoning policy impact toward English class dynamic, teachers' and schools' efforts in improving students' English skills.

Then, the researchers conducted focused-group discussion (FGD) with each group of three highperforming students and three low-performing students. The FGD was conducted to confront statements from the teachers. FGD data were transcribed and coded as the students' comments on teacher characteristics, class activities, English materials, relation with teachers, and relation among friends.

Table 1. Research Participant Description

\begin{tabular}{ll|l|l|l}
\hline No & Subjects & $\begin{array}{l}\text { Years of teaching } \\
\text { experience }\end{array}$ & School & \multicolumn{2}{c}{ Age } \\
\hline 1 & Palma (female) & 24 & High-performing & 46 \\
\cline { 3 - 5 } 2 & Pia (female) & 24 & Low-performing & 46 \\
\hline
\end{tabular}

In the second phase, the researchers invited Palma (pseudonym) from a high-performing school and Pia (pseudonym) from a low-performing school to have in-depth interview. The two teachers were invited because they shared the same age and years of teaching experience but presented obvious differences on how they responded to zoning policy implementation. Thus, two big different pictures of teacher identity were demonstrated by these two teachers. The audio-recorded interview lasted for 30 minutes for each teacher and it was also transcribed and categorized in themes, namely teacher expectation, perception on zoning policy, moral purpose, and classroom dynamic. In order to enrich the data, field-notes regarding matters of the school ecosystem were taken.

\section{Result And Discussion}

Based on the teachers' experiences in facing the zoning policy implementation, there were three aspects respectively revealing the English teacher identity such as, teachers' beliefs on zoning policy implementation, teachers' expectation and moral purpose maintenance, and class dynamics. Table 2 depicts the identity of the two teachers, namely Palma and Pia.

Table 2. English Teacher Identity in Zoning Policy Implementation

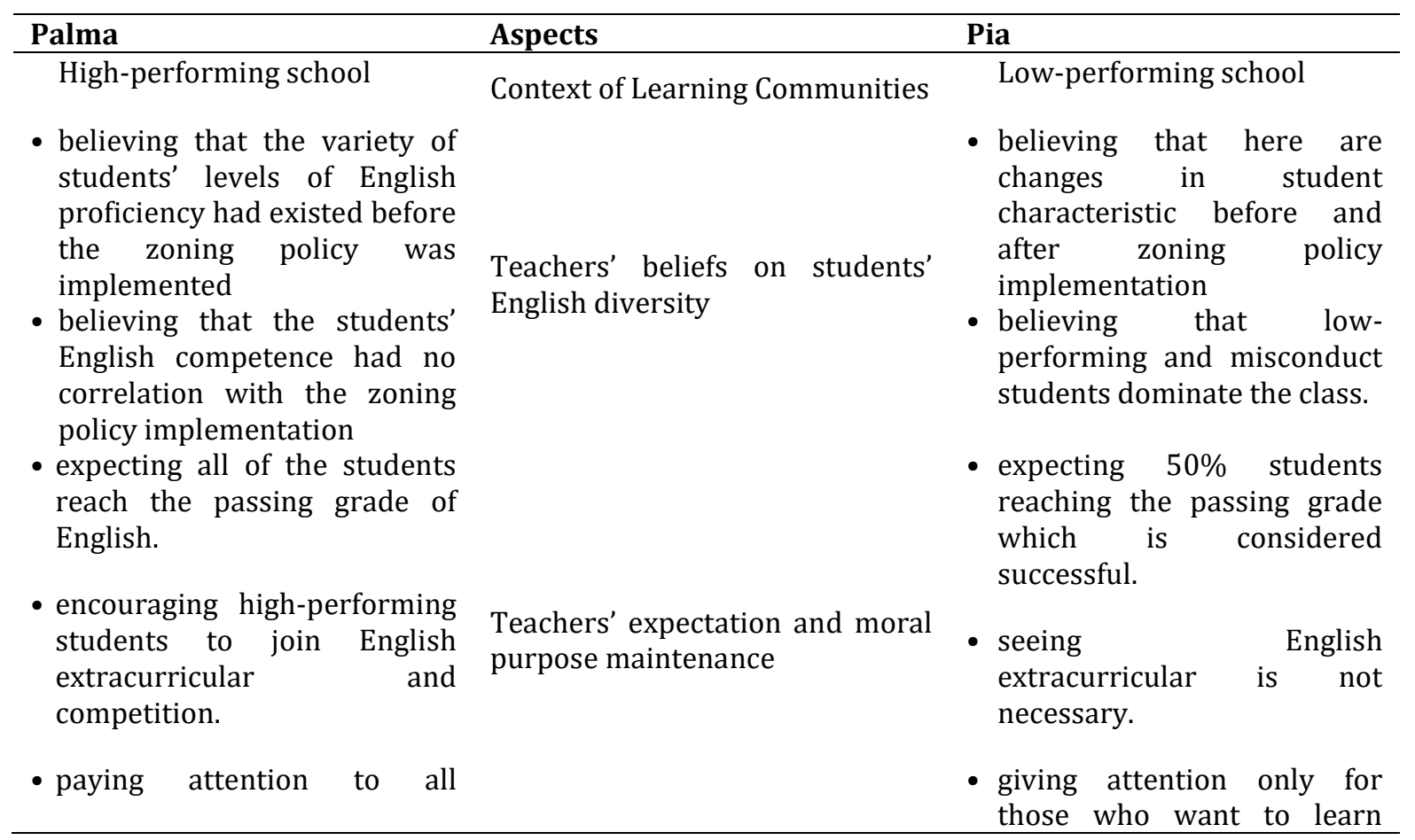




\begin{tabular}{|c|c|c|}
\hline Palma & Aspects & Pia \\
\hline students she teaches & & English. \\
\hline $\begin{array}{l}\text { - } \begin{array}{l}\text { conducting clinical } \\
\text { consultation for low- } \\
\text { performing students }\end{array} \\
\text { - prioritizing teaching }\end{array}$ & & $\begin{array}{l}\text { - no time for clinical } \\
\text { consultation } \\
\text { - prioritizing administrative } \\
\text { tasks }\end{array}$ \\
\hline $\begin{array}{l}\text { - making use of current topics } \\
\text { among students to create } \\
\text { learning activities } \\
\text { - using different materials } \\
\text { based on students' grade level }\end{array}$ & Class dynamics & $\begin{array}{l}\text { - conducting repetition and } \\
\text { memorizing as class } \\
\text { activities } \\
\text { - using the same materials for } \\
\text { all students' grade level }\end{array}$ \\
\hline
\end{tabular}

The three aspects regarding English teacher identity constructions were correlated each other and constructed within the zoning policy implementation and school culture. Adapting the layers of ecosystem of influences from Bahr \& Mellor (2016), this research found that the way teachers responded to the new policy was affected by the environment in which the teachers played their roles as educators. In this context, the outer layer was zoning policy. The zoning policy was implemented by the schools with their own cultural aspects as either high or low-performing learning communities.

Identity is shaped through oneself followed by the situation of school ecological contexts (Viskovic \& Robson, 2001). The ways schools responded to the zoning policy influenced how teachers saw themselves in the current circumstances of the policy implementation. It shaped teachers' beliefs towards the students' characteristics. Teachers' beliefs influenced teachers' expectations and moral purpose maintenance towards their students. Further, it impacts the class dynamics as the output of their beliefs and expectations.

\section{Teachers' Belief}

Palma, who came from the high-performing school, stated her school had housed students with different English proficiencies long before the zoning policy was implemented. In contrast to the previous student enrollment policy, the zoning policy mandates all public schools to admit all students within the zoning area. Her school, traditionally labeled only for A-students, is currently forced to admit students of lower academic performance. Therefore, the students become more heterogenous in terms of academic backgrounds. Despite a huge change in student demographics, Palma remains to believe that in terms of English, there is no such a huge difference:

'Students' ability has been varied for years. There are students who join this school under the scheme of zoning policy. They turned out to perform well. We also have regular students who happen to need more guidance to improve their English skills." [Palma, interview]

English classes in this high-performing school, in the eyes of Palma, have not been negatively influenced by the zoning policy implementation in her school. On the other hand, Pia, who came from a low-performing school, showed different perspectives on zoning policy implementation in her school and its impacts. Pia believed that there was a change in student characteristic before and after zoning policy implementation. For Pia, it was easier to handle students who joined the school prior to zoning policy implementation.

"Before it was implemented, the characteristics of the students were easy to handle. They were qualified compared to current students. The selection was based on academic performance. Now, those who have low academic performance are allowed to join this school." [Pia, interview]

In Pia's recollection, there are now more diverse students in her class. Prior to zoning policy implementation, her school housed a more homogenous group. Located at the outskirt of Yogyakarta City, it would admit those average students. Smarter students would head to high schools in the city. Now, she finds misbehaving, low-performing students to share the same room with high-performing ones. Unfortunately, the former turn out be more dominant, making her hard to control the class.

Teacher beliefs and characteristics can influence the teaching and classroom dynamics. In effect, different teachers' characteristics, as one of them can be shown from their beliefs, contribute to different 
students' outcome (Rubie-Davies, Flint, \& McDonald, 2012). Palma and Pia had different beliefs on the zoning policy implementation and their characteristics of students. Their beliefs, then, differently affected their expectation and moral purpose maintenance towards their students' English ability.

\section{Teachers' Expectation and Moral Purposes}

Two teachers from different schools showed different expectation toward the students in English class. Firstly, the researchers discussed about Palma. Palma was an English teacher of a high-performing school in the city of Yogyakarta. The school was recognized as a powerful learning community. Palma stated that every student had his/her own potential and not all of them had good ability in English.

"I encourage the students who are capable in English skills to join English extracurricular; and I also invite those who have low ability in English to come in my clinical consultation. I keep telling them that English is important for their future career." [Palma, interview]

Palma also added that all students had a right to be guided by the teacher. She stated that whether the students had high or low performance in English skills, all of them should improve regarding their future. Palma kept reminding her students that learning English was their responsibility. She believed that after her students graduated from senior high school, their English capability would be needed for their future study in the university. Moreover, Palma also said that the school had set the passing grade of the subject competence score, including English.

"Our school has set the passing grade in every subject. As an English teacher, I have responsibility to guide my students to reach the passing grade. I believe that everyone can improve."[Palma, interview]

Palma added that the school supported the students to participate in English debate competitions. Palma always invited a debate coach to train her students who would join a debate competition as the school fully supported such activity. Further, as the school had joint-program with a sister school in Australia for a student exchange program, Palma, who was also in charge of this program, encouraged her students to join this program. She believed that the students joining this program would have new experience to widen their horizon of knowledge.

Palma's expectation on her students' performance was different from Pia who taught in a lowperforming school. Pia stated that in the daily performance there was only one until three students who were able to reach the passing grade. Moreover, Pia said that she also paid attention to the students who showed goodwill to learn but she let the students who were demotivated in learning English. She felt that there was nothing she could do for the students who showed no courage in learning English. Pia also explained English extracurricular in her school:

"Our school used to have English club extracurricular. We employed an outsourcing teacher since we didn't have time to manage such activity; even to supervise, we had no time." [Pia, interview]

Further, Pia added that financial problem became one of the constraints in developing the students' English skill. When there was an English debate competition, for example, the school often did not participate because it was hard for the students to pay for it, such as to invite debate coach and to pay participation fee.

Besides things related to English extracurricular, Pia told her way to deal with low-performing students. She explained that she had little time to open clinical consultation for the students due to areat amount of administrative work. In addition, she mentioned that she was not a private teacher so that her focus was in classical teaching and learning activities.

This finding depicts teachers with high and low expectations towards their students. A high expectation teacher tends to spend more time on affording agenda for students' learning (de Boer, Timmermans, \& van der Werf, 2018). It is depicted by Palma who was the English teacher of a high-performing school in which she encouraged her high-performing students in English to join activities to develop their English skills. Moreover, she set her time to guide her low-performing students to have personal clinical consultation outside the class.

On the other hand, a teacher who has low expectation towards the students tends to hardly provide less chances for particular group of students (de Boer et al., 2018). Pia who taught at a low-performing school showed low-expectation toward her students. Thus, she would let her be demotivated students to 
do anything they wanted. In other words, she did not want to spend a little bit more energy for her students to improve their English as she thought that it would bring no significant changes in students' performance. Pia's conduct is actually influenced by her learning community in which sufficient support from the school is barely provided.

\section{Class Dynamic}

The ways teachers made adjustments in teaching and method were triggered by their personal identity (Pennington \& Richards, 2016). This study clearly presents how two teachers, Palma and Pia, who came from two different school cultures, had different approaches in teaching. Based on the findings, it was clear that Palma tended to focus on the students' productive skills while Pia focused on written grammar exercises. The classroom dynamics of the two teachers brought different impression in students about their teachers. The students identified Palma as a communicative teacher and Pia as a technical teacher. In contrast with Pia, Palma appears to welcome demographic changes in her school

\section{Conclussion}

Based on the research conducted with English teachers in both high and low-performing school in Yogyakarta, it can be concluded that the teachers had different perspectives in seeing zoning policy that leads to teacher identity. The two teachers stated that zoning policy brought impacts to the school dynamics, particularly student characteristics. The school culture as a part of the school ecosystem plays an influential role in shaping their beliefs toward the policy implementation. Further, their beliefs construct their identity as English teachers reflected in the ways they act within class dynamic and their students see them.

The discussion of this study is limited to English teacher identity construction in the context of high and low-performing schools in Yogyakarta Province. Due to the small numbers of the research subjects, the result of this study is not to be generalized to other contexts. Future research is suggested to critically investigate teachers' responses to zoning policy in broader scope in Indonesia. Quantitative approach for such research can also be applied to gain bigger pictures on the phenomenon..

\section{Reference}

Adiputra, A. R., Karsidi, R., \& Haryono, B. (2019). Stakeholders' perception about zoning system of new students enrollment programme (PPDB) at SMA Negeri 2 Sukoharjo in the academic year 2018/2019. In Seminar Nasional Pendidikan KALUNI (Vol. 2, pp. 466-479).

Ali, K., Bakar, A., Supriyati, Y., \& Hanafi, I. (2019). Evaluation of Admission Student Policy based on Zoning System for Acceleration Education Quality in Indonesia. Journal of Management Info, 6(2), 19-24. https://doi.org/10.31580/jmi.v6i2.883.

Amirin, T. M., Wijayanti, W., \& Safruddin, C. (2016). Kondisi insani dan material sekolah menengah negeri "pilihan kedua" di kota Yogyakarta. Jurnal Penelitian Ilmu Pendidikan, 9(1), 1-11.

Ary, D., Jacobs, L. C., \& Sorensen, C. K. (2010). Introduction to Research in Education (8th ed.). Wadswoth: Cengage Learning. Retrieved from https://books.google.co.id/books?id=FqF7n0zGJm0C

Bahr, N., \& Mellor, S. (2016). Australian Education Review: Building quality in teaching and teacher education. Victoria: Australian Council for Educational Research Press. Retrieved from www.acer.edu.au/aer.

Bintoro, R. F. A. (2018). Persepsi masyarakat terhadap implementasi kebijakan zonasi sekolah dalam penerimaan peserta didik baru (PPDB) tingkat SMA tahun ajaran 2017/2018 di kota Samarinda. Jurnal Riset Pembangunan, 1(20), 48-57.

de Boer, H., Timmermans, A. C., \& van der Werf, M. P. C. (2018). The effects of teacher expectation interventions on teachers ' expectations and student achievement: narrative review and metaanalysis. Educational Research and Evaluation An International Journal on Theory and Practice, 3611, 180-200. https://doi.org/10.1080/13803611.2018.1550834. 
Hoerudin, C. W. (2019). Evaluation of new student admission policy based on zonation system in Bandung City. JISPO, 9(2), 351-361.

Hong, J., Francis, D. C., \& Schutz, P. A. (2018). Research on Teacher Identity: Common Themes , Implications, and Future Directions, 243-251.

Kaplan, A., \& Garner, J. K. (2018). Teacher identity and motivation: The dynamic systems model of role identity. In Research on Teacher Identity (pp. 71-82). Springer.

Pennington, M. C., \& Richards, J. C. (2016). Teacher Identity in Language Teaching : Integrating Personal , Contextual , and Professional Factors. RELC Journal, 1-19. https://doi.org/10.1177/0033688216631219.

Perdana, N. S. (2019). Implementasi PPDB zonasi dalam upaya pemerataan akses dan mutu pendidikan. Jurnal Pendidikan Glasser, 3(1).

Richardson, P. W., \& Watt, H. M. G. (2018). Teacher professional identity and career motivation: A lifespan perspective. In Research on Teacher Identity (pp. 37-48). Springer.

Rubie-davies, C. M., Flint, A., \& Mcdonald, L. G. (2012). Teacher beliefs, teacher characteristics , and school contextual factors: What are the relationships?, 270-288. https://doi.org/10.1111/j.20448279.2011.02025.x.

Viskovic, A., \& Robson, J. (2001). Community and Identity: experiences and dilemmas of vocational teachers in post-school contexts. Journal of In-Service Education, 27(2), 221-236. 